\title{
Л.В.Саяпина ${ }^{1}$, А.С.Абдрашитова ${ }^{2}$, Р.Н.Лобач ${ }^{3}$, А.В.Комратов ${ }^{1}$, А.Н.Малахаева ${ }^{2}$, О.Ю.Ляшова ${ }^{2}$, Т.В.Валова ${ }^{2}$, М.В.Храмов ${ }^{4}$ Н.Г.Гефан ${ }^{5}$
}

\section{ДИАГНОСТИЧЕСКАЯ ЭФФЕКТИВНОСТЬ ИММУНОГЛОБУЛИНОВ ДИАГНОСТИЧЕСКИХ ФЛУОРЕСЦИРУЮЩИХ СИБИРЕЯЗВЕННЫХ ВЕГЕТАТИВНЫХ АДСОРБИРОВАННЫХ ПО ДАННЫМ МЕДИЦИНСКИХ ИСПЫТАНИИ}

\author{
${ }^{I}$ ФББУ «Научный центр экспертизы средств медииинского применения», Москва, \\ ${ }^{2}$ ФКУЗ «Российский научно-исследовательский противочумный институт «Микроб», Саратов; \\ ${ }^{3}$ ФККУ «294-й Центр по проведению спасательных операџий особого риска» МЧС России, Москва; \\ ${ }^{4}$ ФБУН «Государственный научный иентр прикладной микробиологии и биотехнологии», Оболенск;

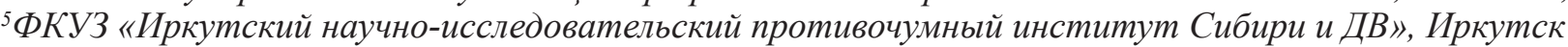

Изучена диагностическая эффективность (специфическая активность, чувствительность, специфичность, воспроизводимость) иммуноглобулинов флуоресцирующих сибиреязвенных вегетативных. На основании данных, полученных в медицинских исследованиях, препарат рекомендован к регистрации в Российской Федерации в качестве изделия медицинского назначения.

Ключевые слова: Bacillus anthracis, Bacillus spp., иммуноглобулины диагностические флуоресцирующие вегетативные сибиреязвенные, диагностическая эффективность.

L.V.Sayapina ${ }^{1}$, A.S.Abdrashitova ${ }^{2}$, R.N.Lobach ${ }^{3}$, A.V.Komratov ${ }^{1}$, A.N.Malakhaeva ${ }^{2}$, O.Yu.Lyashova ${ }^{2}$, T.V.Valova ${ }^{2}$, M.V.Khramov ${ }^{4}$, N.G.Gefan ${ }^{5}$

\section{Diagnostic Efficiency of Adsorbed Anthrax Vegetative Fluorescent Immunoglobulins Demonstrated in the Medical Trials}

${ }^{1}$ Scientific Center for Expertise of Medical Products, Moscow; 'Russian Research Anti-Plague Institute "Microbe", Saratov; ${ }^{3} 294^{\text {th }}$ Center for Carrying out Rescue Operations of Extra Risk, Moscow; ${ }^{4}$ State Scientific Center for Applied Microbiology and Biotechnology, Obolensk; Irkutsk Research Anti-Plague Institute, Irkutsk

Studied is the diagnostic efficiency (specific activity, sensitivity, specificity, reproducibility) of anthrax vegetative fluorescent immunoglobulins. Based on the data, received in medical trials, this preparation is recommended for registration as a product for medical application in the Russian Federation.

Key words: Bacillus anthracis, Bacillus spp., anthrax vegetative fluorescent diagnostic immunoglobulins, diagnostic efficiency.

Сибирская язва - инфекционная болезнь животных и человека, которая, возникнув в какой-либо местности, может сохраняться на многие десятилетия и вызывать повторные вспышки [13]. На территории России за период с 1900 по 2010 год зарегистрировано более 35 тыс. стационарно неблагополучных по сибирской язве пунктов и более 70 тыс. вспышек инфекции. На протяжении последних 5 лет заболеваемость остается на высоком уровне и не имеет тенденции к снижению $[4,6]$. Анализ заболеваемости сибирской язвой людей, проведенный А.Г.Рязановой и соавт. [8], позволяет прогнозировать сохранение заболеваемости на территории Российской Федерации в среднем до 10 случаев в год.

Лабораторными критериями установления диагноза сибирской язвы являются положительные результаты в ПЦР, МФА, иммуносерологических методах, выделение и идентификация культуры сибиреязвенного микроба бактериологическим методом $[7,9]$. Несмотря на постоянное усовершенствование лабораторной диагностики сибирской язвы, эта проблема до сих пор в достаточной мере не решена $[3,6]$. Одной из основных причин является недостаточное обеспечение лабораторных служб зарегистрирован- ными препаратами. В настоящее время не вызывает сомнения тот факт, что важную роль в лабораторной диагностике сибирской язвы играет ПЦР-анализ [1, $5,10,13]$. Особое значение метод приобретает при подтверждении заболевания, когда выделение культуры затруднено.

Метод флуоресцирующих антител (МФА) также относится к основным методам индикации, так как является достаточно информативным, обеспечивающим быстрое и достоверное обнаружение возбудителя сибирской язвы на этапах ранней диагностики. Предварительное заключение с использованием данного метода может быть дано через 3-5 ч после поступления материала.

Положительные результаты, полученные с помощью МФА, позволяют сделать предварительный вывод о наличии возбудителя сибирской язвы или его антигенов в исследуемом биологическом материале или объектах внешней среды и своевременно начать проведение противоэпидемиологических, профилактических и терапевтических мероприятий.

До настоящего времени зарегистрированные препараты для выявления возбудителя сибирской язвы в объектах окружающей среды и биологи- 
ческом материале методом МФА отсутствовали. Учитывая вышеизложенное, в Ставропольском научно-исследовательском противочумном институте разработаны иммуноглобулины диагностические флуоресцирующие сибиреязвенные вегетативные адсорбированные сухие, представляющие собой иммуноглобулиновую фракцию к водорастворимому антигену вегетативной формы Bacillus anthracis, выделенную из гипериммунной кроличьей сыворотки, адсорбированную на основе магноиммуносорбентов водорастворимыми антигенами штаммов B. cereus 8, B. cereus 104, B. cereus 111, B. cereus 250. Иммуноглобулины предназначены для обнаружения вегетативной формы B. anthracis в реакции иммунофлуоресценции (РИФ) в мазках из чистых культур, объектах окружающей среды (почва, подстилка, вода, продовольственное сырье, фураж) и биологического материала.

Основная цель работы - определение диагностической эффективности (специфическая активность, чувствительность, специфичность, воспроизводимость) иммуноглобулинов для решения вопроса о целесообразности их регистрации в качестве изделий медицинского назначения в Российской Федерации.

Предварительно в ФГУН ГИСК им. Л.А.Тарасевича была проведена оценка качества трех лабораторных серий препарата на соответствие требованиям проекта технических условий (ТУ) и подготовлен протокол медицинских испытаний. Ученым советом ФГУН ГИСК им. Л.А.Тарасевича (протокол № 6 от 27 апреля 2010 г.) принято решение о проведении медицинских исследований иммуноглобулинов на четырех базах (лаборатории препаратов против чумы и других особо опасных инфекций ФГУН ГИСК им. Л.А.Тарасевича, ФКУЗ РосНИПЧИ «Микроб», ФКУЗ ИркутскНИПЧИ Сибири и Дальнего Востока и ФБУН ГНЦ ПМБ (Оболенск).

\section{Материалы и методы}

В работе была изучена экспериментальная серия иммуноглобулинов № 1-08 в течение срока ее годности. В связи с тем, что отсутствует препарат сравнения, в качестве сравнения применяли широко используемый бактериологический тест на гемолиз. Материалами для исследования служили чистые культуры Bacillus anthracis и других видов Bacillus, которые были подобраны в ГКПБ «М» РосНИПЧИ «Микроб». Исследование проб объектов окружающей среды (вода, почва) проведены на базе ФКУЗ ИркутскНИПЧИ Сибири и Дальнего Востока; пробы объектов окружающей среды (смывы с объектов внешней среды, корма) и биологического материала (мясо от животного) - на базе ФБУН ГНЦ ПМБ (Оболенск). Каждый опыт проводили с соблюдением принципов строго контролируемого эксперимента в соответствии с протоколом медицинских исследований препарата. Используемые в работе штаммы были зашифрованы сотрудниками, не принимающими уча- стия в приготовлении мазков и учете результатов.

Всего исследовано 47 штаммов B. anthracis, B. cereus, B. subtilis, B. thuringiensis, B. megaterium, B. anthracoides, 225 проб объектов внешней среды (вода, почва, смывы с объектов внешней среды, корма) и биологического материала (мясо), искусственно инфицированных $B$. anthracis в концентрациях $1 \cdot 10^{6}, 1 \cdot 10^{7}, 1 \cdot 10^{8}$ м.к./мл и гетерологичными микроорганизмами (B. subtilis, B. megaterium, B. cereus, $B$. thuringiensis, $B$. anthracoides) в концентрации $1 \cdot 10^{8}$ м.к./мл. Все штаммы были типичными по культурально-морфологическим, биохимическим и генетическим свойствам.

Учитывая назначение сибиреязвенных иммуноглобулинов, особое внимание уделялось подготовке проб из объектов окружающей среды, почвы, фуража и мяса для получения вегетативной формы сибиреязвенного микроба.

Препарат изучали по физико-химическим свойствам; определению рабочего разведения (наибольшее разведение препарата, при котором возможно достоверное обнаружение возбудителя); чувствительности (способность препарата в рабочем разведении выявлять в исследуемых пробах чистых культур минимальные концентрации B. anthracis); специфической активности (процент правильно идентифицированных штаммов B. anthracis и выявленных положительных проб объектов окружающей среды и биологического материала к числу инфицированных); специфичности (процент отрицательных результатов при исследовании проб, инфицированных гетерологичными микроорганизмами); воспроизводимости (процент совпадений результатов исследования положительных и отрицательных проб); продолжительности анализа в часах.

Микроскопию мазков осуществляли с помощью люминесцентного микроскопа «Carl Zeiss Primo Star» под иммерсионным объективом, применяя иммерсионное не флуоресцирующее масло.

Результаты оценивали по 4-крестовой системе: 4 креста - сверкающая флуоресценция зеленоватожелтого цвета оболочки микробной клетки, четко контрастирующая с темным телом клетки; 3 креста яркая флуоресценция зеленовато-желтого цвета оболочки микробной клетки; 2 креста или 1 крест слабое свечение всей клетки. Специфическим считали свечение с яркостью на 4 или 3 креста (при просмотре 30 и более полей зрения), свечение с яркостью 2 или 1 крест считали неспецифическим и не учитывали.

При постановке теста на гемолиз (метод сравнения) исследуемые культуры высевали бактериологической петлей секторами на чашки Петри с агаром Хоттингера (pH 7,1 10,1$)$ с 5 \% дефибринированной крови барана и инкубировали в термостате при температуре $(35 \pm 1)^{\circ} \mathrm{C}$ в течение $(20 \pm 2)$ ч, после чего учитывали результат. Сибиреязвенный микроб не должен лизировать эритроциты барана в отличие от большинства родственных спорообразующих сапро- 
фитов, образующих широкую зону гемолиза вокруг выросших колоний.

\section{Результаты и обсуждение}

В результате проведенных исследований установлено, что испытуемый препарат представляет собой аморфную пористую массу желто-оранжевого цвета, после растворения в 0,5 мл дистиллированной воды в течение 1 мин - прозрачная опалесцирующая жидкость желто-оранжевого цвета, $\mathrm{pH}$ растворенного препарата - 8,0 (норма от 7,5 до 8,5).

Согласно паспортным данным иммуноглобулины выявляли штаммы сибиреязвенного микроба в рабочем разведении 1:128. Специфическую активность иммуноглобулинов определяли при просмотре мазков, приготовленных из 16 штаммов B. anthracis в концентрации $1,0 \cdot 10^{8}$ м.к./мл и окрашенных препаратом в разведениях от 1:8 до 1:256. Было установлено, что препарат в рабочем разведении 1:128 выявлял только 62,5 \% исследуемых штаммов сибиреязвенного микроба. Поэтому за рабочее разведение опытных иммуноглобулинов было принято разведение $1: 64$, о чем свидетельствовало яркое зеленовато-желтое свечение интенсивностью на 3-4 креста у 93,8 \% исследованных штаммов $B$. anthracis. Полученные данные соответствуют требованиям проекта нормативной документации, так как препарат в рабочем разведении не менее 1:16 должен вызывать специфическое свечение вегетативной формы сибиреязвенного микроба в концентрации $1,0 \cdot 10^{8}$ м.к./мл с интенсивностью на 3-4 креста.

Определение чувствительности препарата по способности выявлять в рабочем разведении минимальные концентрации сибиреязвенного микроба в мазках, приготовленных из взвесей чистых культур 5 штаммов $B$. anthracis с концентрациями от $1 \cdot 10^{4}$ до $1 \cdot 10^{8}$ м.к./мл, позволило выявить высокую чувствительность испытуемого препарата. При просмотре 30 полей зрения в мазках наблюдали специфическое свечение с интенсивностью на 3-4 креста 1-2 и более микробных клеток B. anthracis в концентрации $5,0 \cdot 10^{5}$ м.к./мл. В тесте на гемолиз (метод сравнения) чистые культуры штаммов B. anthracis были правильно идентифицированы в $100 \%$ случаев. Все исследуемые штаммы $B$. anthracis не лизировали эритроциты барана.

Специфичность новых иммуноглобулинов изучали на 32 близкородственных и гетерологичных штаммах микроорганизмов. В результате проведенных испытаний зарегистрировано специфическое свечение на 3 креста 8 штаммов других видов Bacillus, окрашенных сибиреязвенными иммуноглобулинами в рабочем разведении 1:64. В общей сложности неспецифические реакции были обнаружены в $25 \%$ случаев, что составляет достаточно высокий процент. Невысокую специфичность препарата (75\%) можно объяснить генетическим родством (до 90 \% гомологии) сибиреязвенного микроорганизма с другими видами рода Bacillus [11]. Анализ 5000 хромосомных генов сибиреязвенного микроба выявил лишь 150 отличий между ними и генами $B$. cereus и B. thuringiensis. При высеве всех гетерологичных штаммов на агаре Хоттингера с кровью барана вокруг выросших колоний отмечалась зона гемолиза.

Воспроизводимость совпадения положительных и отрицательных результатов с помощью исследуемых иммуноглобулинов составила $100 \%$. Исследования, проведенные в 10 повторностях, при постановке анализа в разные дни и разными исполнителями показали, что во всех определениях со штаммом $B$. anthracis получены совпадающие положительные результаты, во всех случаях со штаммом B. cereus - отрицательные результаты.

Продолжительность анализа при исследовании чистых культур с помощью иммуноглобулинов составила 2,5-3 ч и $(20 \pm 2)$ ч при исследовании объектов окружающей среды и биологического материала. Показано, что положительный ответ при исследовании чистых культур методом гемолиза можно выдать через 20 ч и через 40 ч при исследовании проб объектов окружающей среды и биологического материала. Несомненно, по срокам получения заключения при исследовании подозрительного материала с помощью сибиреязвенных иммуноглобулинов метод МФА имеет преимущество перед бактериологическим методом.

Анализ результатов исследований, проведенных на базе ФБУН ГНЦ ПМБ (Оболенск), проб объектов окружающей среды (смывы с объектов внешней среды, корма) и биологического материала (мясо), искусственно инфицированных $B$. anthracis, показал, что сибиреязвенный микроб с помощью испытуемых иммуноглобулинов обнаружен в $100 \%$ случаев. В разведении 1:128 иммуноглобулины вызывали специфическое свечение сибиреязвенного микроба в мазках интенсивностью на 3-4 креста. Чувствительность препарата составила $1,0 \cdot 10^{6}$ м.к./мл. Отмечена высокая специфичность препарата, так как со всеми гетерологичными штаммами были получены отрицательные результаты. На базе ФКУЗ ИркутскНИПЧИ Сибири и Дальнего Востока при испытании иммуноглобулинов диагностических флуоресцирующих во время исследования проб объектов окружающей среды (вода, почва), искусственно инфицированных $B$. anthracis, также подтверждена высокая диагностическая эффективность испытуемого препарата. В разведении 1:128 препарат выявлял $B$. anthracis в минимальной концентрации $1,0 \cdot 10^{6}$ спор/мл в $100 \%$ случаев.

Сводные данные о результатах изучения диагностической эффективности иммуноглобулинов диагностических флуоресцирующих сибиреязвенных вегетативных адсорбированных сухих представлены в таблице.

Полученные данные позволили внести изменения в проект нормативной документации, касающиеся уточнения названия, состава и назначения 
Сводные данные испытаний диагностической эффективности иммуноглобулинов флуоресцирующих сибиреязвенных вегетативных адсорбированных сухих

\begin{tabular}{|c|c|c|c|}
\hline \multirow{2}{*}{ Показатели } & Количество & Результаты исследований \\
\cline { 3 - 4 } & $\begin{array}{c}\text { проб } \\
\text { тест на гемолиз }\end{array}$ & $\begin{array}{c}\text { иммуногобулины сибиреязвенные } \\
\text { вегетативные }\end{array}$ & \\
\hline
\end{tabular}

Минимальное количество микроорганизмов $B$. anthracis, выявляемое в МФА, м.к./мЛ

Процент $(\mathrm{P} \pm \mathrm{p})$ - правильно идентифицированных штаммов $B$. anthracis

Процент (Р $\pm \mathrm{p})$ отрицательных результатов с гетерологичными микроорганизмами

Процент $(\mathrm{P} \pm \mathrm{p})$ выявляемых штаммов $B$. anthracis в пробах объектов окружающей среды

Процент $(\mathrm{P} \pm \mathrm{p})$ отрицательных результатов с гетерологичными микроорганизмами в пробах объектов окружающей среды

Процент $(\mathrm{P} \pm \mathrm{p})$ правильно установленных видов микроорганизмов при проведении теста на гемолиз

Воспроизводимость- Процент $(\mathrm{P} \pm \mathrm{p})$ совпадений результатов исследования положительных и отрицательных проб

Скорость учета результатов (с учетом подготовки всех материалов), в ч

$5,0 \cdot 10^{5}-1 \cdot 0^{6}$

16

32

225

225

48

20

20 при исследовании проб чистых культур и 2,5-3 при исследовании проб объектов окружающей среды и биологического материала
20 при исследовании проб чистых культур и 40 при исследовании проб объектов окружающей среды и биологического материала препарата, дополнить раздел «Спецификация». Существенные изменения были внесены в методику обеззараживания мазков при приготовлении их из спорообразующих микроорганизмов. При оценке качества поступивших первых серий сибиреязвенных вегетативных иммуноглобулинов на соответствие препарата требованиям нормативной документации было выявлено, что иммуноглобулины, даже в разведении 1:16 (норма не менее 1:16), не вызывали специфического свечения сибиреязвенных штаммов. Вместе с тем, по данным авторов, иммуноглобулины выявляли штаммы сибиреязвенного микроба в разведении 1:128. При выяснении причин было установлено, что обеззараживание мазков, приготовленных из сибиреязвенных штаммов, авторы проводили 96 \% спиртом без добавления 3 \% перекиси водорода, использование которой негативно воздействует на специфическое свечение при окраске мазков препаратом. В процессе нашей работы мазки обеззараживали в соответствии с требованиями СП 1.3.1285-03 [2], которые предусматривают обязательное добавление к спирту перекиси водорода. Авторам было рекомендовано провести дополнительные исследования на этапе приготовления мазков. В дальнейшем в проект нормативной документации были внесены дополнения по приготовлению мазков, заключающиеся в промывке стекол с мазками после их обеззараживания в дистиллированной воде в течение 5 мин.

Таким образом, в результате медицинских исследований на четырех базах установлена высокая специфическая активность сибиреязвенных иммуноглобулинов, обеспечивающих специфическое зеленовато-желтое свечение штаммов B. anthracis в вегетативной форме в мазках из чистых культур, биологического материала и объектов внешней среды в концентрации $1,0 \cdot 10^{8}$ м.к./мл. Чувствительность препарата по результатам всех исследований установлена от $5,0 \cdot 10^{5}$ до $1 \cdot 10^{6}$ м.к./мл. Показана диагностическая равноценность иммуноглобулинов и теста на гемолиз при исследовании специфической активности. При изучении специфичности препарата с гетерологичными микроорганизмами более точным оказался тест на гемолиз (100\%), тогда как специфичность испытуемых иммуноглобулинов составила 75 \%. При этом получение результатов значительно быстрее при исследовании с помощью иммуноглобулинов, чем при исследовании бактериологическим методом.

Проведенные исследования позволили рекомендовать иммуноглобулины флуоресцирующие сибиреязвенные вегетативные к регистрации в качестве изделия медицинского назначения для специфической индикации при исследовании чистых культур возбудителя сибиреязвенного микроба, биологического материала и объектов внешней среды при диагностике сибирской язвы учреждениями здравоохранения (Регистрационное удостоверение № ФСР 2011/11338 от 12 июля 2011 г.).

\section{СПИСОК ЛИТЕРАТУРЫ}

1. Абдрашитова А.С., Саяпина Л.В., Малахаева А.Н. и др. Изучение диагностической ценности Наборов реагентов для выявления ДНК Bacillus anthracis и Brucella spp. в биологическом материале и объектах окружающей среды методом ПЦР с гибридизационно-флуоресцентной детекцией в медицинских приемочных испытаниях. В кн.: Диагностика, лечение и профилактика опасных и особо опасных инфекционных заболеваний. Биотехнология. Киров; 2008. С. 30-3.

2. Безопасность работы с микроорганизмами I-II групп патогенности (опасности). СП 1.3.1285-03. Бюл. норм. и метод док. Госсанэпиднадзора. 2003; 3(13):61-144.

3. Куличенко А.Н., Еременко Е.И., Буравиева Н.П., Рязанова А.Г. Диагностика сибирской язвы в Российской Федерации. Журн. микробиол., эпидемиол. и иммунобиол. 2010; 5:62-6.

4. Куличенко А.Н., Малечкая О.В., Дубянский В.М., Еременко

E.И. Актуальность проблемы болезней, общих для человека и животных (бруцеллез, сибирская язва), и КГЛ в рамках пригра- 
ничного сотрудничества. В кн.: Вопросы реагирования на чрезвычайные ситуации санитарно-эпидемиологического характера. Астрахань; 2011. С. 81-4.

5. Окунев В.Б., Пикалов И.Н., Тучков И.В. Опыт использования генодиагностики в целях оптимизации эпидемиологического надзора за сибирской язвой. Эпидемиол. и инф. бол. 2000; 4:17-20.

6. Онищенко Г.Г., Кожухов В.В., редакторы. Сибирская язва: актуальные проблемы разработки и внедрения медицинских средств защиты. М.: Медицина; 2010. 423 с.

7. Рязанова А.Г., Еременко Е. И., Цыганкова О И., Цыганкова E.A. Усовершенствование методов идентификации атипичных штаммов возбудителя сибирской язвы и их дифференциация от близкородственных бацилл. Журн. микробиол., эпидемиол. и иммунобиол. 2009; 3:76-80.

8. Рязанова А.Г., Еременко Е.И., Буравиева Н.П., Цыганкова О.И., Цыганкова Е.А., Аксенова Л.Ю. и др. Эпидемиологическая ситуация по сибирской язве в Российской Федерации: анализ заболеваемости в 2010 г. и прогноз на 2011 г. Пробл. особо опасных инф. 2011; 1(107):42-5.

9. Саяпина Л.В., Абдрашитова А.С., Малахаева А.Н. и др. Характеристика нового бактериофага диагностического сибиреязвенного гамма А-26 жидкого. Биопрепараты. Профилактика, диагностика, лечение. 2011; 1(41):36-9.

10. Саяпина Л.В., Анисимова Т.И., Тучков И.В. и др. Изучение активности и специфичности тест-системы для выявления ДНК Bacillus anthracis методом полимеразной цепной реакции. В кн.: Диагностика, лечение и профилактика опасных инфекционных заболеваний. Биотехнология. Ветеринария. Киров; 1998. C. $213-14$.

11. Цыганкова О.И., Еременко Е.И., Цыганкова Е.А., Буравиева Н.П., Рязанова А.Г. Фенотипические и генетические особенности культурально-морфологических вариантов Bacillus anthracis. Журн. микробиол., эпидемиол. и иммунобиол. 2008 ; 4:6-11.

12. Черкасский Б.Л. Эпидемиология и профилактика сибирской язвы. М.; 2002. 384 с.

13. Read T.D., Peterson S.N., Tourasse N. et al. The genome sequence of $B$. anthracis Ames and comparison to closely-related bacteria. Nature. 2003; 423:81-6.

\section{References (Presented are the Russian sources in the order of citation in the original article)}

1. Abdrashitova A.S., Sayapina L.V., Malakhaeva A.N. et al. [Examination of diagnostic value of reagent kit for Bacillus anthracis and Brucella spp DNA detection in biological material and environmental objects by means of PCR with hybridization-fluorescent detection in medical accepting trials]. In: [Diagnostics, Treatment and Prevention of Dangerous and cepting trials]. In: [Diagnostics, Treatment and Prevention of Dange
Particularly Dangerous Infectious Diseases]. Kirov; 2008. P.30-3

2. [Safety of work with microorganisms of the I-II pathogenic-
. ity groups. SR 1.3.1285-03]. Byul. Norm. Metod. Dok. Gossanepidnadzora. 2003; 3(13):61-144

3. Kulichenko A.N., Eremenko E.I., Buravtseva N.P., Ryazanova A.G [Diagnostic of anthrax in Russia]. Zh. Mikrobiol. Epidemiol. Immunobio 2010; 5:62-6.

4. Kulichenko A.N., Maletskaya O.V., Dubyansky V.M., Eremenko E.I. [Diseases common to man and animals (brucellosis, anthrax) and CCHF in the scope of cross-border cooperation. The Importance of Problem]. In: [Problems of Response to the Emergency Situations of Sanitary and Epidemiological
Character]. Astrakhan, 2011. P.81-4.

5. Okunev V.B., Pikalov I.N., Tuchkov I.V. [The experience of use of gene diagnostics for the purpose of optimization of epidemiological surveillance for anthrax]. Epidemiol. Infek. Bol. 2000; 4:17-20.

6. Onishchenko G.G., Kozhukhov V.V. editors. [Anthrax: Current Problems of Development and Introduction of Medical Protection Means]. M.; 2010. 423p.

7. Ryazanova A.G., Eremenko E.I., Tsygankova O.I., Tsygankova E.A.
10. 7. Ryazanova A.G., Eremenko E.I., Tsygankova O.I., Isygankova E.A.
[Improvement of methods for identification of atypical anthrax strains and their differentiation from closely related bacilli]. Zh. Microbiol. Epidemiol. Immunobiol. 2009; 3:76-80.

8. Ryazanova A.G., Eremenko E.I., Buravtseva N.P., Tsygankova O.I., Tsygankova E.A., Aksenova L.Yu. et al. [Epidemiological situation on anthrax in the Russian Federation: analysis of morbidity in 2010, prognosis for 2011]. Probl. Osobo Opasn. Infek. 2011; 1(107):42-5.

9. Sayapina L.V., Abdrashitova A.S., Malakhaeva A.N. et al. [Characteristics of new anthrax diagnostic liquid bacteriophage gamma A-26]. Biopreparaty. Prophilak. Diagn. Lechenie. 2011; 1(41):36-9

10. Sayapina L.V., Anisimova T.I., Tuchkov I.V. et al. [Examination of the activity and specificity of test system for Bacillus anthracis DNA detection by polymerase chain reaction]. In: [Diagnostics, Treatment and Prophylaxis of Dangerous Infectious Diseases]. Kirov; 1998. P.213-14.

11. Tsygankova O.I., Eremenko E.I., Tsygankova E.A., Buravtseva N.P., Ryazanova A.G. [Phenotipic and genetic features of cultural-morphologic variants of Bacillus anthracis]. Zh. Mikrobiol. Epidemiol. Immunobiol. 2008; $4: 6-11$. 2002. 384 p.

12. Cherkassky B.L. [Epidemiology and Prophylaxis of Anthrax]. M.;

Authors:

Sayapina L.V., Komratov A.V. Scientific Center for Expertise of Medical Products. 8, Petrovsky Bulvar, Moscow, 127051, Russia.

Abdrashitova A.S., Malakhaeva A.N., Lyashova O.Yu., Valova T.V. Russian Research Anti-Plague Institute "Microbe". 46, Universitetskaya St., Saratov, 410005, Russia. E-mail: rusrapi@microbe.ru

Lobach R.N. 294 ${ }^{\text {th }}$ Center for Carrying out Rescue Operations of Extra Risk. Moscow, Russia.

Khramov M.V. State Research Center for Applied Microbiology and Biotechnology. Obolensk, Moscow Region, 142279, Russia. E-mail: info@obolensk.org

Gefan N.G. Irkutsk Research Anti-Plague Institute of Siberia and Far East. 78, Trilissera St., Irkutsk, 664047, Russia. E-mail: adm@chumin.irkutsk.ru

\section{Об авторах:}

Саяпина Л.В., Комратов А.В. Научный центр экспертизы средств медицинского применения. 127051, Москва, Петровский бульвар, 8.

Абдрашитова А.С., Малахаева А.Н., Ляшова О.Ю., Валова Т.В. Российский научно-исследовательский противочумный институт «Микроб». 410005, Саратов, ул. Университетская, 46. E-mail: rusrapi@ microbe.ru

Лобач Р.Н. 294-й Центр по проведению спасательных операций особого риска МЧС России. Москва.

Храмов M.B. Государственный научный центр прикладной микробиологии и биотехнологии. 142279, Московская обл., п. Оболенск. E-mail: info@obolensk.org

Гефан Н.Г. Иркутский научно-исследовательский противочумный институт Сибири и Дальнего Востока. 664047, Иркутск, ул. Трилиссера 78. E-mail: adm@chumin.irkutsk.ru 